\title{
Mexican native tomatoes as rootstocks to increase fruit yield
}

Mario de Jesūs Velasco-Alvarado ${ }^{1}$, Ricardo Lobato-Ortiz ${ }^{1 *}$,

José Jesús García-Zavala ${ }^{1}$, Rogelio Castro-Brindis ${ }^{2}$, Serafin Cruz-Izquierdo ${ }^{1}$, Tarsicio Corona-Torres ${ }^{1}$, and Magda Karina Moedano-Mariano ${ }^{1}$

\section{ABSTRACT}

Tomato (Solanum lycopersicum L.) is one of the most economically important vegetables in the world. Mexico is considered as its center of domestication and there is a large genetic diversity. Grafting in tomato has grown for various purposes including the increase of yield. An alternative use of native tomato genotypes is as rootstocks for grafting improved tomato. The objective of this work was to evaluate native accessions of tomato as rootstocks to identify outstanding genotypes for their potential to be used as rootstocks in tomato production. An experiment was conducted for two cropping cycles (2014 and 2015) in greenhouse and hydroponic conditions, in a randomized complete block design (RCBD) with three replicates and 10 plants per experimental unit. Treatments were formed by a combination of nine native tomatoes and two commercial rootstocks with two hybrids used as scions. Twelve traits were recorded and most of the treatments were significantly different $(P<0.05)$ from each other for these traits. The accessions LOR-22, LOR-77, LOR-81, LOR-84, LOR-95 and LOR-100 with the hybrid 'El Cid', and LOR-81, LOR-84 and LOR-100 with the hybrid 'Sun 7705 ', increased significantly yield by $19 \%$ and $22 \%$, respectively, compared to ungrafted control. Moreover, characteristics related to fruit quality were preserved with grafting. The best combination scion/rootstock ('Cid'/100) yielded $30 \%$ higher than hybrid 'El Cid' without grafting and $16 \%$ higher than the commercial rootstock 'Multifort'. This allowed identifying genotypes of Mexican native tomatoes with great potential to be used as rootstocks or as source of germplasm for rootstock development.

Key words: Grafting, natives, rootstocks, Solanum lycopersicum, yield.

${ }^{1}$ Postgrado de Recursos Genéticos y Productividad-Genética, Colegio de Postgraduados (COLPOS), Texcoco 56230, Estado de México, México. .Corresponding author (rlobato@colpos.mx).

${ }^{2}$ Universidad Autónoma Chapingo, Departamento de Fitotecnia, Texcoco 56230, Estado de México, México.

Received: 10 February 2017.

Accepted: 17 June 2017.

doi:10.4067/S0718-58392017000300187

\section{INTRODUCTION}

Tomato (Solanum lycopersicum L.) is within the three most economically important vegetable crops in Mexico, along with chili (Capsicum spp.) and potato (Solanum tuberosum L.) In 2014,52000 ha were planted with a production of 2.8 million ton (SIAP, 2015). For Mexico, the tomato is particularly important because it is considered center of domestication for this species (Peralta and Spooner, 2007); which allows having a wide native genetic diversity useful for tomato breeding.

In recent years, there have been studies about the agronomic and morphological diversity of native tomatoes from Mexico with the purpose of knowing their genetic variability (JuárezLópez et al., 2009; Crisanto-Juárez et al., 2010; BonillaBarrientos et al., 2014; Estrada-Trejo et al., 2014), their extent of exploration and conservation (Chávez et al., 2011; LobatoOrtiz et al., 2012) and their use for tomato breeding (MartínezVázquez et al., 2016).

Because of environmental unfavorable conditions in which the Mexican native genotypes of tomato have been adapted, they have developed tolerance or resistance to biotic and abiotic stresses, which may be useful in their genetic improvement; as indicated by Flores-González et al. (2012), Estrada-Trejo et al. (2014), Sanjuan-Lara et al. (2015), who have reported native tomato genotypes with tolerance to salinity. Traditionally, Mexican native tomatoes have been used as local varieties in the gastronomy of rural communities in different regions of Mexico (Chávez et al., 2011) or as a source of germplasm for breeding (Martínez-Vázquez et al., 2016).

An immediate alternative use of the Mexican native tomatoes is as rootstocks; i.e. providing only the abundant radical part to take advantage of their characteristics such as their capacity to absorb water and nutrients, their salinity tolerance, disease resistance, vigor, among others. Cortez (2010) reported that resistance to the psyllid Bactericera cockerelli (Sulc.) and Liriomyza spp., present in a wild genotype of S. lycopersicum L. var. cerasiforme (Alef.) Voss was transferred to the scion using this as rootstock.

Chronologically, grafting in vegetables was first used to control Fusarium in watermelon (Citrullus lanatus (Thunb.) Matsum. \& Nakai) (Tateishi, 1927). This technique has been applied to other crops such as melon (Cucumis melo L.), cucumber (Cucumis sativus L.), pepper (Capsicum annuum L.), eggplant (Solanum melongena L.) and mainly in tomato (Lee, 1994). Currently, grafting purposes have been diversified, 
and they include: increasing nutrient absorption (Colla et al., 2010; Velasco-Alvarado et al., 2016), improving the efficiency of irrigation water (Rouphael et al., 2008), increasing yield and tolerance to salinity (Colla et al., 2006) and increasing tolerance to toxic elements (Rouphael et al., 2008; Edelstein y Ben-Hur, 2015).

However, despite all the advantages that grafting offers, the technique may be unattractive to some tomato growers, due to the high cost of grafted seedlings, which increases the overall production cost (Rysin et al., 2015). Nevertheless, one of the most significant concepts for tomato growers is the cost of the rootstock seed, which is mostly the F1 generation from interspecific crosses between S. lycopersicum L. and S. habrochaites S. Knapp \& D.M Spooner (King et al., 2010). The seed of these rootstocks is expensive because it is imported and marketed by multinational companies in USD or Euros, so understanding this issue is necessary to identify and produce alternative rootstocks at a lower cost to the tomato growers. Thus, the objective of this work was to evaluate Mexican native tomato collections as rootstocks in order to identify genotypes with potential to be used as rootstocks by tomato growers to improve yield and maintain or improve fruit quality characteristics or as source of germplasm for rootstock development.

\section{MATERIALS AND METHODS}

\section{Location}

This work was carried out in a greenhouse with 600-grade polyethylene cover ( $80 \%$ light transmission), with a tunnel-type design with top vent, located in the Campus Montecillo (19³0' N, 98 53' W; 2250 m a.s.l.), Colegio de Postgraduados, Mexico. Two crop cycles were conducted during the spring-summer of 2014 and 2015 under hydroponic conditions with a mean annual temperature of 18.2 and $18.6^{\circ} \mathrm{C}$, respectively.

\section{Plant materials and growth conditions}

Nine native tomato accessions belong to S. lycopersicum were used as rootstocks (Table 1). This genetic material was selected from a total of 40 open pollinated (OP) genotypes because of their characteristics to be used as rootstocks, such as stem diameter, plant height and number of leaves, characteristics used as indicators of plant vigor. The commercial rootstocks 'Maxifort' and
'Multifort' were used as controls. On the other hand, the commercial hybrids 'Sun 7705' and 'El Cid' were used as scions. The sowing was carried out in polystyrene trays of 128 cavities with Kekkila commercial mixture as substrate (Kekkila, Vantaa, Finland). The nine collections, 'El Cid' and 'Sun 7705' were sown the same day, and the commercial rootstocks $2 \mathrm{~d}$ later in order to homogenize the stem diameter and improve the engraftment of grafts; one seed per cavity was sown and irrigation was applied to saturation. For seedlings nutrition the Steiner (1984) nutrient solution to $25 \%$ was supplied. Grafting was carried out using the method of splicing (Lee, 1994) at 28 days after sowing (das) in seedlings with $9.0 \mathrm{~cm}$ height, stem diameter between 1.8 and $2.0 \mathrm{~mm}$ and four fully expanded leaves. The grafted seedlings were placed for 10 $\mathrm{d}$ in a chamber for engraftment ( $5 \mathrm{~m}$ long, $4 \mathrm{~m}$ wide and 2.5 $\mathrm{m}$ high). During that period of post-grafting, the chamber conditions were $25^{\circ} \mathrm{C}, 90 \% \mathrm{RH}$ and $111 \mu \mathrm{mol} \mathrm{m} \mathrm{m}^{-2}$ in the first $5 \mathrm{~d}$ post-grafting and $28{ }^{\circ} \mathrm{C}, 70 \% \mathrm{RH}$ and 148 $\mu \mathrm{mol} \mathrm{m} \mathrm{m}^{-2} \mathrm{~s}^{1}$ in the $5 \mathrm{~d}$ after.

The transplanting was carried out 38 das in polypropylene pots $(40 \times 40 \mathrm{~cm}, 12 \mathrm{~L})$ filled with volcanic pumice rock (tezontle is the local name of this material) of $4 \mathrm{~mm}$ in diameter (particle size), planting one plant per pot, they were conducted to one stem and trained in vertical position all the time. To obtain a population density of 2.7 plants $\mathrm{m}^{-2}$ (10 clusters each), seedlings were transplanted with $35 \mathrm{~cm}$ between plants in a row and 2 $\mathrm{m}$ between rows, each row with two lines (double line, common commercial system in Mexico). Twenty two treatments were established, which were obtained from combining nine native collections and two commercial checks ('Maxifort' and 'Multifort') as rootstocks with two scions. Also as controls 'El Cid' and 'Sun 7705' both ungrafted and self-grafted were used, in a randomized complete block design with three replicates, where the experimental unit had 10 plants. For fertilization, the universal formula of Steiner (1984) was employed and the concentration supplied was according to the phenological stage: 0 to $40 \mathrm{~d}$ after transplanting (dat) at $50 \%$ and 41 dat to the end of cycle at $100 \%$. The following products were applied: imidacloprid, flonicamid and lambda cyalotrina and clorantraniliprol to control whitefly (Bemisia tabaci Gennadius) and paratrioza (Bactericera cockerelli); captan, copper chloride and metalaxil and clorotalonil for the prevention of late blight (Phytophthora infestans).

Table 1. Mexican native tomato collections used as rootstocks and their geographical origin.

\begin{tabular}{|c|c|c|c|c|c|c|}
\hline Collections & Locality & Municipality & $\begin{array}{l}\text { Latitude } \\
\mathrm{N}\end{array}$ & $\underset{\text { W }}{\text { Longitude }}$ & $\begin{array}{l}\text { Altitude } \\
\text { m }\end{array}$ & Type \\
\hline LOR-22 & Ecatlán & Jonotla, Puebla & $20^{\circ} 00^{\prime}$ & $97^{\circ} 36^{\prime}$ & 725 & Kidney \\
\hline LOR-77 & La Ceiba & Xicotepec, Puebla & $20^{\circ} 13^{\prime}$ & $97^{\circ} 45^{\prime}$ & 1470 & Kidney \\
\hline LOR-81 & Altepexi & Altepexi, Puebla & $18^{\circ} 24^{\prime}$ & $97^{\circ} 15^{\prime}$ & 1240 & Square \\
\hline LOR-84 & Altepexi & Altepexi, Puebla & $18^{\circ} 24^{\prime}$ & $97^{\circ} 15^{\prime}$ & 1240 & Square \\
\hline LOR-95 & Tehuacán & Tehuacán, Puebla & $18^{\circ} 37^{\prime}$ & $97^{\circ} 14^{\prime}$ & 1600 & Square \\
\hline LOR-100 & Santa Cruz Xitla & Santa Cruz Xitla, Oaxaca & $16^{\circ} 17^{\prime}$ & $96^{\circ} 37^{\prime}$ & 1800 & Kidney \\
\hline LOR-117 & Necaxa & Juan Galindo, Puebla & $20^{\circ} 12^{\prime}$ & $97^{\circ} 57^{\prime}$ & 1400 & Kidney \\
\hline LOR-119 & La Ceiba & Xicotepec, Puebla & $20^{\circ} 13^{\prime}$ & $97^{\circ} 45^{\prime}$ & 1470 & Kidney \\
\hline LOR-120 & Huauchinango & Huauchinango, Puebla & $20^{\circ} 07^{\prime}$ & $97^{\circ} 55^{\prime}$ & 1600 & Kidney \\
\hline
\end{tabular}




\section{Traits measurements and statistical analysis}

The number of days to flowering (DF) was recorded when the plants started anthesis in the first flower; the number of days to ripening (DR) was recorded when the color of the fruit changed from green to red (at first cluster). Plant height $(\mathrm{PH})$ was measured from the stem base to the apex of the plant at 100 dat; stem diameter (SD) was measured with a digital vernier (Mitutoyo, Aurora, Illinois, USA) at the mid part of plant height at 100 dat. The number of fruits per plant (NF) was also counted and the yield was the total marketable fruit weight per plant. From a sample of five fruits per plant, average fruit weight (AFW), length (FL) and width (FW) of fruit in mm, fruit shape (S; FL/FW) were obtained. As well as, fruit firmness (FIR) measured with a universal force gage (Force Five, model VSF-30, Wagner Instruments, Greenwich, Connecticut, USA), with a plunger head of $0.8 \mathrm{~mm}$, and total soluble solids (TSS) content were measure with a digital refractometer (PA-mark 1, Atago, Tokyo, Japan).

The statistical analysis of data was performed with the Statistical Analysis Systems (SAS; 9.0) General Linear Model (GLM) procedure (SAS Institute, 2002). A combined ANOVA for cropping cycles and a Tukey test $(\alpha=0.05)$ for all pair-wise mean comparisons were performed.

\section{RESULTS AND DISCUSSION}

There was a significance $(\mathrm{p}<0.05)$ between cycles, treatments and Cycle $\times$ Treatment interaction for most traits except for NF and $\mathrm{S}$ in cycles, for FW in treatments and for FL and $\mathrm{S}$ of fruit in the interaction (Table 2). Although the work was carried out under greenhouse conditions, significant differences for treatment throughout cycles were observed, while a significant interaction between genotypes and cycles was also reported by Bonilla-Barrientos et al. (2014) in tomato native genotypes evaluated under greenhouse conditions in two crop cycles. In this study, cycle one (C1) was more lateness by $6 \mathrm{~d}$ than cycle two (C2), according to the averages of DF and DR. For yield, $\mathrm{C} 1$ outperformed significantly to the $\mathrm{C} 2$, which was related to a higher AFW, since in $\mathrm{C} 2$ the AFW was significantly lower (Table 2).

Some native collections used as rootstocks increased significantly tomato fruit yield (Table 3 ); the ungrafted commercial hybrid 'El Cid' (6.6 kg) was surpassed significantly by combinations with collections 22 (7.6 $\mathrm{kg}), 77(8.4 \mathrm{~kg}), 81(7.6 \mathrm{~kg}), 84(7.7 \mathrm{~kg}), 95(7.7 \mathrm{~kg})$ and $100(8.7 \mathrm{~kg})$ and the commercial rootstock 'Multifort' $(7.7 \mathrm{~kg})$, confirming the advantage of using rootstocks to increase yield performance (Turhan et al., 2011). The outstanding combination ('Cid'/100) surpassed 30\% the yield of ungrafted 'El Cid', representing this an increase of $2.0 \mathrm{~kg} \mathrm{plant}^{-1}$; on average these six native collections

Table 3. Mean comparisons for yield and yield components in grafted tomato with native collections and commercial rootstocks.

\begin{tabular}{|c|c|c|c|c|c|c|}
\hline \multirow[b]{2}{*}{ Rootstocks } & \multicolumn{3}{|c|}{ 'El Cid' } & \multicolumn{3}{|c|}{ 'Sun 7705' } \\
\hline & Yield & $\mathrm{NF}$ & AFW & Yield & $\mathrm{NF}$ & AFW \\
\hline & \multicolumn{2}{|c|}{$\mathrm{kg}$} & $\mathrm{g}$ & \multicolumn{2}{|c|}{$\mathrm{kg}$} & $\mathrm{g}$ \\
\hline Non-grafted & $6.6 \mathrm{f}-\mathrm{i}$ & $70.2 \mathrm{ab}$ & $110.6 \mathrm{~b}-\mathrm{d}$ & $5.7 \mathrm{j}$ & $60.5 \mathrm{c}-\mathrm{g}$ & $106.6 \mathrm{~d}$ \\
\hline Self-grafted & $6.4 \mathrm{~h}-\mathrm{j}$ & $70.3 \mathrm{ab}$ & $111.4 \mathrm{~b}-\mathrm{d}$ & $5.7 \mathrm{j}$ & $59.7 \mathrm{~d}-\mathrm{g}$ & $111.2 \mathrm{~b}-\mathrm{d}$ \\
\hline LOR-22 & 7.6c-e & $71.2 \mathrm{ab}$ & 119.6a-d & $6.5 \mathrm{~g}-\mathrm{j}$ & $57.2 \mathrm{~g}$ & $114.5 \mathrm{a}-\mathrm{d}$ \\
\hline LOR-77 & $8.4 \mathrm{ab}$ & $68.8 \mathrm{a}-\mathrm{c}$ & $119.8 \mathrm{a}-\mathrm{d}$ & $6.2 \mathrm{ij}$ & $60.7 \mathrm{c}-\mathrm{g}$ & $109.5 \mathrm{~cd}$ \\
\hline LOR-81 & 7.6c-e & $69.7 \mathrm{ab}$ & $124.3 \mathrm{a}-\mathrm{c}$ & $6.8 \mathrm{e}-\mathrm{i}$ & $58.7 \mathrm{e}-\mathrm{g}$ & $119.8 \mathrm{a}-\mathrm{d}$ \\
\hline LOR-84 & $7.7 b c$ & $67.2 \mathrm{a}-\mathrm{d}$ & 121.1a-d & $7.3 \mathrm{c}-\mathrm{g}$ & $59.7 \mathrm{~d}-\mathrm{g}$ & $120.5 \mathrm{a}-\mathrm{d}$ \\
\hline LOR-95 & $7.7 b-d$ & $68.8 \mathrm{a}-\mathrm{c}$ & $117.4 \mathrm{a}-\mathrm{d}$ & $6.4 \mathrm{~h}-\mathrm{j}$ & $58.2 \mathrm{fg}$ & $112.5 \mathrm{~b}-\mathrm{d}$ \\
\hline LOR-100 & $8.7 \mathrm{a}$ & $71.5 \mathrm{ab}$ & $128.2 \mathrm{a}$ & $7.1 \mathrm{c}-\mathrm{h}$ & $59.3 \mathrm{~d}-\mathrm{g}$ & 116.0a-d \\
\hline LOR-117 & $7.5 \mathrm{c}-\mathrm{f}$ & 67.3a-d & $120.5 \mathrm{a}-\mathrm{d}$ & $6.4 \mathrm{~h}-\mathrm{j}$ & $58.5 \mathrm{fg}$ & $117.7 \mathrm{a}-\mathrm{d}$ \\
\hline LOR-119 & $7.0 \mathrm{c}-\mathrm{i}$ & $63.0 \mathrm{~b}-\mathrm{g}$ & $125.4 \mathrm{ab}$ & $6.4 \mathrm{~g}-\mathrm{j}$ & $58.0 \mathrm{fg}$ & 119.1a-d \\
\hline LOR-120 & $6.8 \mathrm{~d}-\mathrm{i}$ & $66.0 \mathrm{a}-\mathrm{f}$ & $122.8 \mathrm{a}-\mathrm{c}$ & $6.4 \mathrm{~h}-\mathrm{j}$ & $56.8 \mathrm{~g}$ & $114.7 \mathrm{a}-\mathrm{d}$ \\
\hline 'Maxifort' & $7.3 c-f$ & 70.7ab & 113.6a-d & $6.4 \mathrm{~g}-\mathrm{j}$ & $58.5 \mathrm{fg}$ & 116.2a-d \\
\hline 'Multifort' & $7.7 \mathrm{bc}$ & $72.3 \mathrm{a}$ & 113.3a-d & $6.3 \mathrm{~h}-\mathrm{j}$ & $58.3 \mathrm{fg}$ & $110.8 b-d$ \\
\hline
\end{tabular}

Distinct letters in the column indicate significant differences according to Tukey's test $(\mathrm{P} \leq 0.05)$.

Yield: Fruit yield per plant (HSD: 0.83); NF: number of fruit per plant (HSD: 8.6); AFW: average fruit weight (HSD: 15.1); HSD: honest significant difference.

Table 2. ANOVA mean squares of twelve traits in tomato grafted onto nine native collections and two commercial rootstock, and comparison of means between cycles.

\begin{tabular}{|c|c|c|c|c|c|c|c|}
\hline SV & Cycle & Treat & Cycle $\times$ Treat & Error & $\mathrm{CV}(\%)$ & $\overline{\mathrm{y}} \mathrm{C} 1$ & $\overline{\mathrm{y}} \mathrm{C} 2$ \\
\hline YLD & $15.11 * *$ & $3.46^{* *}$ & $1.65^{* *}$ & 0.144 & 5.46 & $7.26 \mathrm{a}$ & $6.63 \mathrm{~b}$ \\
\hline $\mathrm{NF}$ & $16.02 \mathrm{~ns}$ & $186.26 * *$ & $31.11 * *$ & 29.23 & 6.14 & $64.2 \mathrm{a}$ & $63.6 \mathrm{a}$ \\
\hline AFW & $8674.78 * *$ & $128.53 * *$ & $93.46^{*}$ & 54.73 & 6.27 & $124 \mathrm{a}$ & $110 \mathrm{~b}$ \\
\hline FL & $19.74 *$ & $11.04 * *$ & $6.36 \mathrm{~ns}$ & 4.77 & 3.28 & $66.3 \mathrm{a}$ & $67.0 \mathrm{a}$ \\
\hline FW & $23.61 * *$ & $3.32 \mathrm{~ns}$ & $6.66 * *$ & 2.58 & 3.0 & $53.1 \mathrm{a}$ & $54.0 \mathrm{a}$ \\
\hline S & $0.002 \mathrm{~ns}$ & $0.005^{* *}$ & $0.003 \mathrm{~ns}$ & 0.002 & 4.29 & $1.3 \mathrm{a}$ & $1.2 \mathrm{a}$ \\
\hline FIR & $1858.17 * *$ & $25.81^{*}$ & $31.16^{* *}$ & 14.56 & 17.22 & $2.6 \mathrm{a}$ & $1.9 \mathrm{~b}$ \\
\hline TSS & $37.51 * *$ & $0.46^{* *}$ & $0.17 * *$ & 0.05 & 5.99 & $3.3 \mathrm{~b}$ & $4.3 \mathrm{a}$ \\
\hline $\mathrm{DF}$ & $1303.85^{* *}$ & $39.50^{* *}$ & $19.67 * *$ & 1.84 & 5.39 & $28.0 \mathrm{a}$ & $22.2 \mathrm{~b}$ \\
\hline DR & $1869.23^{* *}$ & $55.70^{* *}$ & $23.89^{* *}$ & 2.25 & 1.69 & $91.7 \mathrm{a}$ & $84.8 \mathrm{~b}$ \\
\hline PH & $112217.02^{* *}$ & $2700.66^{* *}$ & $749.18^{* *}$ & 264.06 & 6.18 & $290 a$ & $236 b$ \\
\hline SD & $7.15^{* *}$ & $1.62 * *$ & $1.42 *$ & 0.78 & 7.83 & $11.5 \mathrm{a}$ & $11.1 \mathrm{a}$ \\
\hline DF & 1 & 25 & 25 & 100 & & & \\
\hline
\end{tabular}

SV: Source of variation; Treat: treatments; Cycle $\times$ Treat: cycle per treatment interaction; CV: coefficient of variation; $\bar{y} C 1$ and $\bar{y} C 2:$ average for cycle one and two (mean values with the same letter are nonsignificantly different (Tukey, $\mathrm{P}=0.05$ ); YLD: fruit yield per plant $(\mathrm{kg}$ ); NF: number of fruits per plant; AFW: average fruit weight $(\mathrm{g})$; FL: fruit length $(\mathrm{mm})$; FW: fruit width $(\mathrm{mm})$; S: fruit shape (FL/FW); FIR: firmness (N); TSS: total soluble solids $\left({ }^{\circ}\right.$ Brix); DF: days to flowering; DR: days to ripening; PH: plant height (cm); SD: stem diameter (mm); DF: degrees of freedom.

ns, **, *: nonsignificant or significant at $\mathrm{P} \leq 0.01$ y $\mathrm{P} \leq 0.05$, respectively. 
increased $19 \%$ the yield, while the commercial rootstock 'Multifort' increased it by $16 \%$, demonstrating these results the potential of native tomato genotypes for their use as rootstocks.

With respect to the hybrid 'Sun 7705 ' $(5.7 \mathrm{~kg})$, three native collections used as rootstocks produced higher yield; the collections $81(6.8 \mathrm{~kg}), 84(7.3 \mathrm{~kg})$ and $100(7.1$ $\mathrm{kg}$ ) had an average yield increase of $22 \%$ compared to plants without grafting. In this case, the most outstanding combination was 'Sun' $/ 84$, with an increase of $1.5 \mathrm{~kg}$ per plant, which represented a $26 \%$, outperforming this combination to the commercial rootstock 'Multifort' that yielded $6.3 \mathrm{~kg}$ per plant.

Yield increases were mainly due to an increase in number of fruits $(\mathrm{NF} ; \mathrm{r}=0.65)$ and the average fruit weight (AFW; $r=0.40$ ); however, only the combination ' $\mathrm{Cid} / 100$ ' exceeded the fruit weight of the ungrafted plants, since this combination improved AFW by $16 \%$ (18 g per fruit). The increase in yield of grafted plants is attributed to various characteristics of the rootstock in comparison with nongrafted plants, such as greater absorption of water and nutrients that allows a more efficient fertilization and an increased cytokinin levels (Lee, 1994; Leonardi y Giuffrida, 2006), and a major resistance or tolerance to diseases (Oda, 2002) and abiotic factors (Colla et al., 2010).

Non-grafted plants ('El Cid' and 'Sun 7705') yielded significantly equal to self-grafted plants; this means that the grafting process had no effect on this variable (Table 3 ).

The increase in yield per plant is reflected in the total production per hectare; in Figure 1 native genotypes with the greatest potential for use as rootstocks are shown. According to the population density in this study (2.7 plants $\mathrm{m}^{-2}$ ), with 'El Cid', the collection 100 ('Cid'/100) had a significant yield increase of $54 \mathrm{t} \mathrm{ha}^{-1}$, and on average three native genotypes $(84,77$ and 100) increased the yield up to $44 \mathrm{t} \mathrm{ha}^{-1}$, surpassing the yield increase of the commercial rootstock 'Multifort' ('Cid'/'Multifort'), which increased yield only in $28 \mathrm{t} \mathrm{ha}^{-1}$.
On the other hand, in combinations with 'Sun 7705', the collection 84 ('Sun'/84) improved yield performance up to $41 \mathrm{t} \mathrm{ha}^{-1}$, and on average three collections $(81,100$ and 84 ) increased the fruit production by $35 \mathrm{t} \mathrm{ha}^{-1}$. It is known that grafted seedlings in tomato and other horticultural crops increases the production cost (Djidonou et al., 2013). However, the use of these native accessions like rootstock can reduce the high cost, because this seed is cheaper than commercial rootstocks seeds, besides their yield increases are similar or even superior than them.

In this study, NF for 'El Cid' was significantly higher $(P \leq 0.05)$ than for 'Sun 7705' in ungrafted plants. However, there was no effect of the rootstock for this trait, as all combinations (rootstock/scion) were significantly $(P \leq 0.05)$ similar to ungrafted plants with each scion (Table 3 ). The results of previous investigations on this variable was found to depend on the rootstock/scion combination; for example, Ibrahim et al. (2001) used eight rootstocks of wild relatives of Solanum and found significant differences in number of fruits using $S$. integrifolium and crosses from $S$. melongena $\times S$. integrifolium. Meanwhile, Leonardi and Giuffrida (2006) found differences for this variable with the rootstock 'Beaufort', but not with 'PG3' and 'Energy', using the hybrid 'Rita' as scion.

For traits such as FL, FW and S there were nonsignificant differences $(P \leq 0.05)$ between grafted and ungrafted plants for both scions; this indicates that fruit proportions and shape were maintained for these rootstocks and two scions (Table 4). This result contrasts with those of Turhan et al. (2011), who reported changes in fruit shape in the tomato 'Yeni Talya', 'Swanson' and 'Beril' grafted on the rootstocks 'Beaufort' and 'Arnold'.

The alteration in fruit firmness in grafted plants depends on the rootstock/scion combination (Flores et al., 2010). In the present study, nonsignificant differences $(P \leq 0.05)$ were found between treatments, which means that the combinations of 'El Cid' and 'Sun 7705 ' with the native genotypes and commercial rootstocks did not affect this

Figure 1. Yield per hectare of tomato grafted on three Mexican native accessions and the most outstanding commercial rootstock, using 'El Cid' and 'Sun 7705' scions.

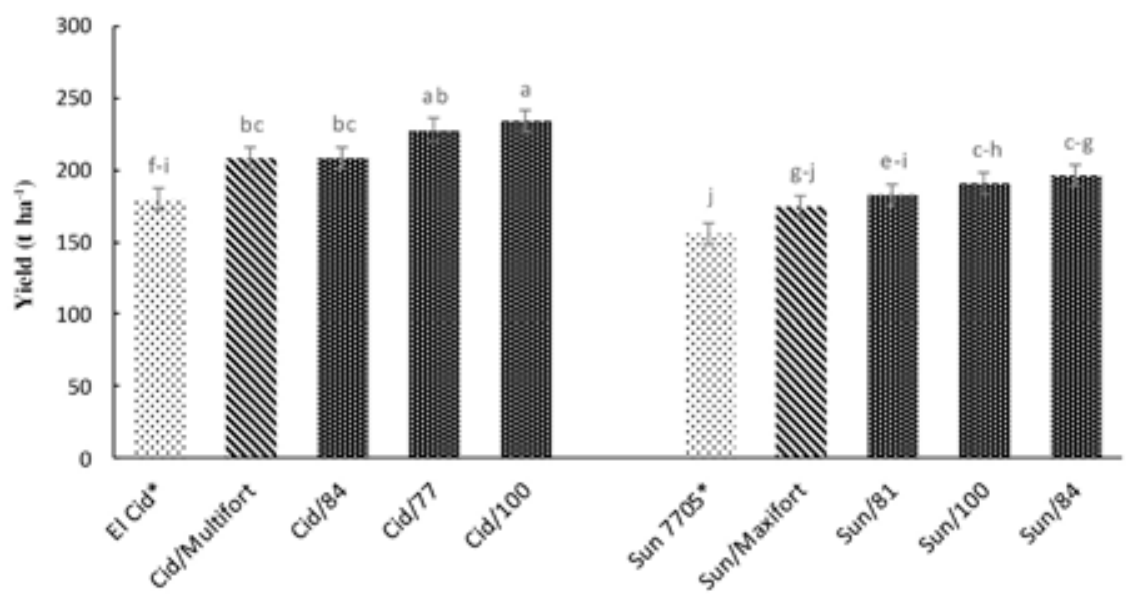

Different letters on bars indicate significant differences between ungrafted plants $(*)$ and different rootstocks according to Tukey test $(\mathrm{P}<0.05)$. Vertical bars correspond to standard error. 
Table 4. Mean comparisons for nine traits in grafted tomato with native collections and commercial rootstocks.

\begin{tabular}{|c|c|c|c|c|c|c|c|c|c|}
\hline & FL & FW & $\mathrm{S}$ & FIR & TSS & $\mathrm{DF}$ & DR & $\mathrm{PH}$ & SD \\
\hline & $\mathrm{mm}$ & $\mathrm{mm}$ & & $\mathrm{N}$ & ${ }^{\circ}$ Brix & $\mathrm{d}$ & $\mathrm{d}$ & $\mathrm{cm}$ & $\mathrm{mm}$ \\
\hline 'El Cid' & $69.9 a$ & $54.1 \mathrm{a}$ & $1.5 \mathrm{a}$ & $2.2 \mathrm{a}$ & $3.7 b-d$ & $17.8 \mathrm{e}$ & $84.5 \mathrm{ij}$ & $284.3 \mathrm{ab}$ & $11.3 \mathrm{a}$ \\
\hline 'Cid' self-graf. & $67.6 a-c$ & $53.7 \mathrm{a}$ & $1.3 \mathrm{ab}$ & $1.8 \mathrm{a}$ & $4.1 \mathrm{ab}$ & $23.7 \mathrm{~cd}$ & $90.3 \mathrm{~b}-\mathrm{e}$ & $258.0 \mathrm{~b}-\mathrm{f}$ & $11.9 \mathrm{a}$ \\
\hline 'Cid'/22 & 67.6a-c & $54.7 \mathrm{a}$ & $1.3 \mathrm{ab}$ & $2.3 \mathrm{a}$ & $3.7 b-d$ & $27.2 \mathrm{ab}$ & $94.0 \mathrm{a}$ & $290.7 \mathrm{ab}$ & $12.1 \mathrm{a}$ \\
\hline 'Cid'/77 & $66.8 \mathrm{a}-\mathrm{c}$ & $53.0 \mathrm{a}$ & $1.3 \mathrm{ab}$ & $2.2 \mathrm{a}$ & $3.6 \mathrm{de}$ & $25.5 b c$ & $91.2 \mathrm{a}-\mathrm{d}$ & $287.2 \mathrm{ab}$ & $11.9 \mathrm{a}$ \\
\hline 'Cid'/81 & $68.7 \mathrm{ab}$ & $53.6 \mathrm{a}$ & $1.3 \mathrm{ab}$ & $1.9 \mathrm{a}$ & $3.9 b-d$ & $26.8 \mathrm{ab}$ & $89.0 \mathrm{c}-\mathrm{g}$ & 264.3a-f & $10.7 \mathrm{a}$ \\
\hline 'Cid'/84 & $66.7 \mathrm{a}-\mathrm{c}$ & $53.6 \mathrm{a}$ & $1.2 \mathrm{ab}$ & $2.0 \mathrm{a}$ & $3.8 \mathrm{~b}-\mathrm{d}$ & $28.5 \mathrm{a}$ & $91.3 \mathrm{a}-\mathrm{c}$ & $273.3 \mathrm{a}-\mathrm{d}$ & $11.1 \mathrm{a}$ \\
\hline 'Cid'/95 & $67.2 \mathrm{a}-\mathrm{c}$ & $52.9 \mathrm{a}$ & $1.3 \mathrm{ab}$ & $1.9 \mathrm{a}$ & $3.6 \mathrm{de}$ & $26.5 \mathrm{a}-\mathrm{c}$ & $92.3 \mathrm{ab}$ & $274.2 \mathrm{a}-\mathrm{d}$ & $10.7 \mathrm{a}$ \\
\hline 'Cid'/100 & $68.0 \mathrm{a}-\mathrm{c}$ & $53.9 \mathrm{a}$ & $1.3 \mathrm{ab}$ & $2.3 \mathrm{a}$ & $3.6 c-e$ & $26.3 \mathrm{a}-\mathrm{c}$ & $89.2 b-g$ & $278.7 \mathrm{a}-\mathrm{c}$ & $11.9 \mathrm{a}$ \\
\hline 'Cid'/117 & $66.8 \mathrm{a}-\mathrm{c}$ & $52.0 \mathrm{a}$ & $1.3 \mathrm{ab}$ & $2.2 \mathrm{a}$ & $3.6 c-e$ & $26.5 \mathrm{a}-\mathrm{c}$ & $90.0 b-f$ & $265.2 \mathrm{a}-\mathrm{f}$ & $11.0 \mathrm{a}$ \\
\hline 'Cid'/119 & 67.6a-c & $53.4 \mathrm{a}$ & $1.3 \mathrm{ab}$ & $2.3 \mathrm{a}$ & $3.7 b-d$ & $26.7 \mathrm{ab}$ & $87.7 \mathrm{e}-\mathrm{i}$ & 267.3a-f & $10.9 \mathrm{a}$ \\
\hline 'Cid'/120 & $67.1 \mathrm{a}-\mathrm{c}$ & $52.9 \mathrm{a}$ & $1.3 \mathrm{ab}$ & $2.2 \mathrm{a}$ & $3.8 \mathrm{~b}-\mathrm{d}$ & $25.3 b c$ & $89.2 b-g$ & $259.5 a-f$ & $11.2 \mathrm{a}$ \\
\hline 'Cid'/'Maxifort' & $66.8 \mathrm{a}-\mathrm{c}$ & $52.6 \mathrm{a}$ & $1.3 \mathrm{ab}$ & $2.2 \mathrm{a}$ & $3.2 \mathrm{e}$ & $25.0 \mathrm{bc}$ & $91.0 \mathrm{a}-\mathrm{d}$ & $294.2 \mathrm{a}$ & $11.6 \mathrm{a}$ \\
\hline 'Cid'/'Multifort' & $67.2 \mathrm{a}-\mathrm{c}$ & $52.7 \mathrm{a}$ & $1.3 \mathrm{ab}$ & $2.1 \mathrm{a}$ & $3.1 \mathrm{e}$ & $25.8 \mathrm{a}-\mathrm{c}$ & $92.3 \mathrm{ab}$ & $292.5 \mathrm{ab}$ & $11.7 \mathrm{a}$ \\
\hline 'Sun 7705' & $65.5 \mathrm{a}-\mathrm{c}$ & $54.5 \mathrm{a}$ & $1.4 \mathrm{ab}$ & $2.3 \mathrm{a}$ & $4.0 \mathrm{a}-\mathrm{d}$ & $17.5 \mathrm{e}$ & $80.0 \mathrm{k}$ & $269.7 \mathrm{a}-\mathrm{e}$ & $11.3 \mathrm{a}$ \\
\hline 'Sun' selfgraf. & 65.6a-c & $52.8 \mathrm{a}$ & $1.2 \mathrm{ab}$ & $2.3 \mathrm{a}$ & $4.4 \mathrm{a}$ & $21.3 \mathrm{~d}$ & $83.7 \mathrm{j}$ & $208.7 \mathrm{~g}$ & $10.3 \mathrm{a}$ \\
\hline 'Sun'/22 & 66.1a-c & $54.0 \mathrm{a}$ & $1.2 \mathrm{ab}$ & $2.5 \mathrm{a}$ & $3.8 b-d$ & $25.7 \mathrm{a}-\mathrm{c}$ & $88.0 \mathrm{~d}-\mathrm{h}$ & $263.0 \mathrm{a}-\mathrm{f}$ & $12.0 \mathrm{a}$ \\
\hline 'Sun'/77 & $63.6 \mathrm{c}$ & $53.3 \mathrm{a}$ & $1.1 \mathrm{~b}$ & $2.5 \mathrm{a}$ & $3.8 \mathrm{~b}-\mathrm{d}$ & $26.0 \mathrm{a}-\mathrm{c}$ & $87.7 \mathrm{e}-\mathrm{i}$ & $264.0 \mathrm{a}-\mathrm{f}$ & $11.6 \mathrm{a}$ \\
\hline 'Sun'/81 & $66.2 \mathrm{a}-\mathrm{c}$ & $54.9 \mathrm{a}$ & $1.2 \mathrm{ab}$ & $2.3 \mathrm{a}$ & $4.0 \mathrm{a}-\mathrm{d}$ & $26.2 \mathrm{a}-\mathrm{c}$ & $87.5 \mathrm{e}-\mathrm{i}$ & $232.3 \mathrm{fg}$ & $10.9 \mathrm{a}$ \\
\hline 'Sun'/84 & $67.0 \mathrm{a}-\mathrm{c}$ & $54.3 \mathrm{a}$ & $1.2 \mathrm{ab}$ & $2.3 \mathrm{a}$ & $4.1 \mathrm{a}-\mathrm{c}$ & $26.2 \mathrm{a}-\mathrm{c}$ & $85.2 \mathrm{~h}-\mathrm{j}$ & $237.7 \mathrm{e}-\mathrm{f}$ & $10.7 \mathrm{a}$ \\
\hline 'Sun'/95 & $63.8 \mathrm{c}$ & $53.5 \mathrm{a}$ & $1.1 \mathrm{~b}$ & $2.2 \mathrm{a}$ & $4.0 \mathrm{a}-\mathrm{d}$ & $25.8 \mathrm{a}-\mathrm{c}$ & $87.0 \mathrm{f}-\mathrm{i}$ & $243.3 \mathrm{c}-\mathrm{f}$ & $10.9 a$ \\
\hline 'Sun'/100 & $66.0 \mathrm{a}-\mathrm{c}$ & $54.2 \mathrm{a}$ & $1.2 \mathrm{ab}$ & $2.5 \mathrm{a}$ & $3.8 \mathrm{~b}-\mathrm{d}$ & $24.8 b c$ & $89.3 b-f$ & 268.7a-e & $11.9 \mathrm{a}$ \\
\hline 'Sun'/117 & $66.5 \mathrm{a}-\mathrm{c}$ & $53.5 \mathrm{a}$ & $1.3 \mathrm{ab}$ & $2.6 \mathrm{a}$ & $4.1 \mathrm{a}-\mathrm{c}$ & $27.3 \mathrm{ab}$ & $87.7 \mathrm{e}-\mathrm{i}$ & $236.3 \mathrm{e}-\mathrm{f}$ & $11.1 \mathrm{a}$ \\
\hline 'Sun'/119 & $67.0 \mathrm{a}-\mathrm{c}$ & $54.4 \mathrm{a}$ & $1.2 \mathrm{ab}$ & $2.4 \mathrm{a}$ & $4.0 \mathrm{a}-\mathrm{d}$ & $25.2 b c$ & $85.5 \mathrm{~h}-\mathrm{j}$ & $238.8 \mathrm{~d}-\mathrm{f}$ & $10.8 \mathrm{a}$ \\
\hline 'Sun'/120 & $66.4 \mathrm{a}-\mathrm{c}$ & $53.5 \mathrm{a}$ & $1.3 \mathrm{ab}$ & $2.6 \mathrm{a}$ & $4.0 \mathrm{a}-\mathrm{d}$ & $25.0 \mathrm{bc}$ & $86.0 \mathrm{~g}-\mathrm{j}$ & 239.7d-f & $10.8 \mathrm{a}$ \\
\hline 'Sun'/'Maxifort' & 65.6a-c & $53.4 \mathrm{a}$ & $1.2 \mathrm{ab}$ & $2.3 \mathrm{a}$ & $3.7 b-d$ & $24.7 b c$ & $87.3 \mathrm{e}-\mathrm{i}$ & $262.7 \mathrm{a}-\mathrm{f}$ & $11.9 \mathrm{a}$ \\
\hline 'Sun'/'Multifort' & $64.8 \mathrm{bc}$ & $52.2 \mathrm{a}$ & $1.3 \mathrm{ab}$ & $2.2 \mathrm{a}$ & $3.7 \mathrm{c}-\mathrm{e}$ & $26.2 \mathrm{a}-\mathrm{c}$ & $88.2 \mathrm{c}-\mathrm{g}$ & $278.2 \mathrm{a}-\mathrm{c}$ & $11.7 \mathrm{a}$ \\
\hline HSD & 4.7 & 3.5 & 0.26 & 0.86 & 0.49 & 2.9 & 3.3 & 35.5 & 1.9 \\
\hline $\mathrm{CV}, \%$ & 3.3 & 3 & 4.3 & 17.2 & 5.9 & 5.4 & 1.7 & 6.2 & 7.8 \\
\hline
\end{tabular}

Distinct letters in the column indicate significant differences according to Tukey's test $(\mathrm{P} \leq 0.05)$.

FL: fruit length; FW: fruit width; S: fruit shape (FL/FW); FIR: firmness; TSS: total soluble solids; DF: days to flowering; DR: days to ripening; PH: plant height; SD: stem diameter; HSD: honest significant difference; CV: coefficient of variation.

trait, which can be interpreted as a positive performance. In the same way, Khah et al. (2006) reported nonsignificant differences in fruit firmness between grafted and nongrafted plants using 'Heman' and 'Primavera' as rootstocks and 'Big Red' as a scion. With regard to TSS content, there is no consensus on the effect of grafting on this variable; some studies have reported a negative effect on this trait (Khah et al., 2006; Turkmen et al., 2010), which may be a disadvantage for the rootstocks used in those works due to that TSS content is one of the most important characteristics for fruit flavor (Saltveit, 2005). In the present study, none of the Mexican native tomato rootstocks reduced the TSS content when 'El Cid' was used as scion, which represents an advantage over the commercial rootstocks ('Maxifort' and 'Multifort'), which had values of 3.2 and $3.1{ }^{\circ}$ Brix, respectively, being a reduction of $14 \%$ and $16 \%$, in the same order, compared to ungrafted plants. The same trend was observed in combinations with 'Sun 7705', where numerically the lowest average values of TSS were also for the commercial rootstocks; however, all treatments were significantly similar (Table 4). Similarly, Pogonyi et al. (2005) found a decrease of TSS content in plants grafted of the tomato hybrid 'Lemance' on the rootstock 'Beaufort'. On the other hand, some researchers as Flores et al. (2010) indicated that fruit quality, like TSS content can also be increased using rootstocks that yield higher ${ }^{\circ}$ Brix.
Earliness in grafted tomato plants is affected due to the time required for the vascular reestablishment after grafting and environmental conditions in the post-grafting phase, mainly by temperature and luminosity (Oda et al., 2003). As it was expected, ungrafted hybrids were earliest for days to flowering (DF) with 18 dat, these were significantly earlier than the self-grafted plants, with differences of 6 and $4 \mathrm{~d}$ for 'El Cid' and 'Sun 7705', respectively. When comparing our native rootstocks with two commercial rootstocks, most of them had very similar earliness (Table 4 ). The post-grafting phase in this work was $10 \mathrm{~d}$, which coincided with the increase in days to flowering in later combinations (' $\mathrm{Cid}$ '/84, 'Sun'/117). A similar behavior for earliness was observed in days to ripening (DR), since ungrafted plants were significantly $(P \leq 0.05)$ earlier than grafted plants for both hybrids ('El Cid' and 'Sun 7705'), except the combination 'Cid'/119. This result is in agreement with those of Godoy et al. (2009), who reported that the harvest was 1-wk earlier in non-grafted plants than in plants grafted on the rootstock 'Maxifort', pointing out that the grafting technique retards the initial development of the plant and consequently days to flowering and ripeness are increased.

For plant height, the effect of native and commercial rootstocks was only significantly higher than in selfgrafting with 'Sun 7705 ' scion and was not with 'El Cid', which means that the effect on plant vigor depends on the 
rootstock/scion combination, as indicated by numerous investigations. 'Sun 7705 ' reduced its height when it was self-grafted, but when rootstocks were used this effect was compensated. The vigor in grafted plants may be increased, reflected this in characteristics such as a greater plant height and stem diameter (Khah et al., 2006). For stem diameter, nonsignificant differences $(P \leq 0.05)$ were observed in the rootstock/scion combinations used in the present study. Both PH and SD had a positive correlation with fruit yield, $r=0.49$ and $r=0.39$, respectively (not shown data), which mean that rootstocks able to increase the plant vigor, may also increase fruit yield.

\section{CONCLUSIONS}

This study has identified Mexican native tomato accessions with potential for rootstocks, as some of them were superior to the commercial rootstocks and increased yield and maintained fruit quality characteristics. The most outstanding collections were LOR-22, LOR-77, LOR-81, LOR-84, LOR-95 and LOR-100 in combination with 'El Cid', while collections LOR-81, LOR-84 and LOR-100 with 'Sun 7705 '. The most outstanding combinations on each scion were 'Cid'/100 and 'Sun'/84, as they exceeded $30 \%$ and $26 \%$ of the yield of ungrafted plants, respectively. So these genotypes of native tomato may be used as rootstocks by tomato growers in the short term or as a source of germplasm for rootstock development.

\section{ACKNOWLEDGEMENTS}

We thank the support provided by the National Council of Science and Technology (CONACYT) and the Colegio de Postgraduados (COLPOS), Mexico, for the support given to this Project.

\section{REFERENCES}

Bonilla-Barrientos, O., Lobato-Ortiz, R., García-Zavala, J.J., CruzIzquierdo, S., Reyes-López, D., Hernández-Leal, E., et al. 2014. Diversidad agronómica y morfológica de tomates arriñonados y tipo pimiento de uso local en Puebla y Oaxaca, México. Revista Fitotecnia Mexicana 37:129-139.

Chávez, S.J., Carrillo, J.C., Vera, A.M., Rodríguez, E., y Lobato, R. 2011. Utilización actual y potencial del jitomate silvestre mexicano. 72 p. Subsistema Nacional de Recursos Fitogenéticos para la Alimentación y la Agricultura (SINAREFI), Secretaria de Agricultura, Ganadería y Desarrollo Rural, Pesca y Alimentación, CIIDIR-Unidad Oaxaca del Instituto Politécnico Nacional e Instituto Tecnológico del Valle de Oaxaca, México.

Colla, G., Rouphael, Y., and Cardarelli, M. 2006. Effect of salinity on yield, fruit quality, leaf gas exchange, and mineral composition of grafted watermelon plants. Hortscience 41:622-627.

Colla, G., Rouphael, Y., Leonardi, C., and Bie, Z. 2010. Role of grafting in vegetable crops grown under saline conditions. Scientia Horticulturae 127:147-155.

Cortez, M.H. 2010. Resistencia a insectos de tomate injertado en parientes silvestres, con énfasis en Bactericera cockerelli Sulc. (Hemiptera: Psyllidae). Bioagro 22:11-16.
Crisanto-Juárez, A.U., Vera-Guzmán, A.M., Chávez-Servia, J.L., y Carrillo-Rodríguez, J.C. 2010. Calidad de frutos de tomates silvestres (Lycopersicon esculentum var. cerasiforme Dunal) de Oaxaca, México. Revista Fitotecnia Mexicana 33:7-13.

Djidonou, D., Gao, Z., and Zhao, X. 2013. Economic analysis of grafted tomato production in sandy soils in North Florida. HortTechnology 23:613-621.

Edelstein, M., and Ben-Hur, M. 2015. Grafting: a useful tool to increase tolerance to toxic elements in vegetables under arid and semiarid conditions. Acta Horticulturae 1086:133-140.

Estrada-Trejo, V., Lobato-Ortiz, R., García-de-los-Santos, G., Carrillo-Castañeda, G., Castillo-González, F., ContrerasMagaña, E., et al. 2014. Diversidad de poblaciones nativas de jitomate para germinación en condiciones Salinas. Revista Mexicana de Ciencias Agrícolas 5:1067-1079.

Flores, B.F., Sanchez-Bel, P., Estan, M.T., MartinezRodriguez, M.M., Moyano, E., Morales, B., et al. 2010. The effectiveness of grafting to improve tomato fruit quality. Scientia Horticulturae 126:211-217.

Flores-González, D., Sandoval-Villa, M., Sánchez-García, P., Ramírez-Vallejo, P., and Rodríguez-García, M.N. 2012. Yield of native genotypes of tomato as affected by electrical conductivity of nutrient solution. Acta Horticulturae 947:69-76.

Godoy, H.H., Castellanos, R.J.Z., Alcántar, G.G., Sandoval, V.M., and Muños, R.J.J. 2009. Efecto del injerto y nutrición de tomate sobre rendimiento, materia seca y extracción de nutrimentos. Terra Latinoamericana 27:1-11.

Ibrahim, M., Munira, M.K., Kabir, M.S., Islam, A.K.M.S., and Miah, M.M.U. 2001. Seed germination and graft compatibility of wild Solanum as rootstock of tomato. Journal of Biological Sciences 1:701-703.

Juárez-López, P., Castro-Brindis, R., Colinas-León, T., RamírezVallejo, P., Sandoval-Villa, M., Reed, D.W., et al. 2009. Evaluación de calidad de frutos de siete genotipos nativos de jitomate (Lycopersicon esculentum var. cerasiforme). Revista Chapingo Serie Horticultura 15:5-9.

Khah, E.M., Kakava, E., Mavromatis, A., Chachalis, D., and Goulas, C. 2006. Effect of grafting on growth and yield of tomato (Lycopersicon esculentum Mill.) in greenhouse and open-field. Journal of Applied Horticulture 8:3-7.

King, S.R., Davis, A.R., Zhang, X., and Crosby, K. 2010. Genetics, breeding and selection of rootstocks for Solanaceae and Cucurbitaceae. Scientia Horticulturae 127:106-111.

Lee, J. 1994. Cultivation of grafted vegetables I. Current status, grafting methods, and benefits. HortScience 29:235-239.

Leonardi, C., and Giuffrida, F. 2006. Variation of plant growth and macronutrient uptake in grafted tomatoes and eggplant on three different rootstocks. European Journal of Horticultural Science 71:97-101.

Lobato-Ortiz, R., Rodríguez-Guzmán, E., Carrillo-Rodríguez, J.C., Chávez-Servía, J.L., Sánchez-Peña, P., y Aguilar-Meléndez, A. 2012. Exploración, colecta y conservación de recursos genéticos de jitomate: Avances de la Red de Jitomate. Sistema Nacional de Recursos Fitogenéticos para la Alimentación y Agricultura (SINAREFI). 54 p. Ed. Secretaría de Agricultura, Ganadería, Desarrollo Rural, Pesca, y Alimentación y Colegio de Postgraduados. Texcoco, México.

Martínez-Vázquez, E. de los A., Lobato-Ortiz, R., GarcíaZavala, J.J., y Reyes-López, D. 2016. Heterosis de cruzas entre líneas de tomate (Solanum lycopersicum L.) nativo mexicano tipo pimiento y líneas tipo saladette. Revista Fitotecnia Mexicana 39:67-77. 
Oda, M. 2002. Grafting of vegetable crops. Science Report Agriculture and Biological Science 54:49-72.

Oda, M., Islam, M., Ikeda, H., and Furukawa, H. 2003. Initiation and development of flower trusses affected by acclimatizing temperature in grafted tomato plugs. Environmental Control in Biology 41:133-139.

Peralta, I.E., and Spooner, D.M. 2007. History, origin and early cultivation of tomato. p. 1-24. In Razdan, M.K., and Mattoo, A.K. (eds.) Genetic improvement of Solanaceous crops. Vol. 2. Tomato. Science Publishers, Enfield, New Hampshire, USA.

Pogonyi, A., Pék, Z., Helyes, L., and Lugasi, A. 2005. Effect of grafting on the tomato's yield, quality and main fruit components in spring forcing. Acta Alimentaria 34:453-462.

Rouphael, Y., Cardarelli, M., Rea, E., and Colla, G. 2008. Grafting a cucumber as a means to minimize cooper toxicity. Environmental and Experimental Botany 63:49-58.

Rysin, O., Rivard, C., and Louws, F.J. 2015. Is vegetable grafting economically viable in the United States: evidence from four different tomato production systems. Acta Horticulturae 1086:79-86.

Saltveit, M.E. 2005. Fruit ripening and fruit quality. p. 145-171. In Huevelink, E. (ed.) Tomato. CABI Publishing, Cambridge, Massachusetts, USA.

Sanjuan-Lara, F., Ramírez, V.P., Sánchez, G.P., Sandoval, V.M., Livera, M.M., Carrillo, R.J.C., et al. 2015. Tolerancia de líneas nativas de tomate (Solanum lycopersicum L.) a la salinidad con $\mathrm{NaCl}$. Interciencia 40:704-709.
SAS Institute. 2002. User's guide of SAS (Statistical Analysis System). 550 p. SAS Institute, Cary, North Carolina, USA.

SIAP. 2015. Producción agropecuaria y pesquera. Sistema de Información Agroalimentaria y Pesquera (SIAP), Ciudad de México, México. Available at http://www.siap.gob.mx/ (accessed December 2015).

Steiner, A.A. 1984. The universal nutrient solution. p. 633650. In Proceedings $6^{\text {th }}$ International Congress on Soilless Culture, Lunteren. International Society for Soilless Culture, Wageningen, The Netherlands.

Tateishi, K. 1927. Grafting watermelon on squash. Japan Journal Horticulture 39:5-8.

Turhan, A., Ozmen, N., Serbeci, M.S., and Seniz, V. 2011. Effects of grafting on different rootstocks on tomato fruit yield and quality. Horticultural Science 38:142-149.

Turkmen, O., Seymen, M., and Dursun, A. 2010. Effects of different rootstocks and cultivars on yield and some yield components of grafted tomato. Bulletin UASVM Horticulture 67:284-291.

Velasco-Alvarado, M.J., Castro-Brindis, R., Castillo-González, A.M., Avitia-Garcia, E., Sahagún-Castellanos, J., y LobatoOrtiz, R. 2016. Composición mineral, biomasa y rendimiento en tomate (Solanum lycopersicum L.) injertado. Interciencia 41:703-708. 